\title{
Evaluation of well-being at work among nursing professionals at a University Hospital
}

\author{
Priscila Castro Alves ${ }^{1}$ \\ Vanessa Faria Neves ${ }^{2}$ \\ Marilia Ferreira Dela Coleta $^{3}$ \\ Áurea de Fátima Oliveira ${ }^{3}$
}

\begin{abstract}
Well-being at work is based on Positive Psychology, and is defined as a psychological state with positive affective links towards work and also towards the organisation. The purpose of this study was to look at the degree of well-being at work among nursing professionals who work at a University hospital and also identify differences between occupational categories and types of work contracts. The sample was made up of 340 professionals who answered valid scales of the following constructs: Work Satisfaction, Involvement with Work and Affective Organisational Commitment. For the analysis of the data we used SPSS, version 12, for descriptive statistics, and also for testing differences between means. The results showed an average level of well-being in the workplace and also differences between professional categories and work regime, when it comes to satisfaction with salaries and promotions, which can have a reflection in the quality of service provided to the patients of this University hospital.
\end{abstract}

Descriptors: Nursing; Job Satisfaction; University Hospitals.

${ }^{1}$ RN, MSc, Universidade Federal de Uberlândia, Brazil.

2 Master's Student, Universidade Federal de Uberlândia, Brazil.

${ }^{3}$ PhD, Profesor, Universidade Federal de Uberlândia, Brazil.

\footnotetext{
Corresponding Author:

Priscila Castro Alves

Universidade Federal de Uberlândia

Diretoria de Qualidade de Vida e Saúde do Servidor

Av. Mato Grosso, 3370

Campus Umuarama

CEP: 38405-314, Uberlândia, MG, Brasil

E-mail: enf.pri@hotmail.com
} 


\title{
Avaliação do bem-estar no trabalho entre profissionais de enfermagem de um hospital universitário
}

Bem-estar no trabalho apoia-se na Psicologia Positiva, sendo definido como um estado psicológico composto por vínculos afetivos positivos com o trabalho e com a organização. Este estudo teve por objetivo conhecer o nível de bem-estar no trabalho de profissionais de Enfermagem que atuam em um hospital universitário e identificar diferenças entre categorias ocupacionais e tipos de contrato de trabalho. A amostra foi composta por 340 profissionais que responderam a escalas válidas dos construtos: Satisfação no Trabalho, Envolvimento com o Trabalho e Comprometimento Organizacional Afetivo. Para análise dos dados utilizou-se o programa SPSS, versão 12, a fim de efetuar estatísticas descritivas e testes de diferença entre médias. Os resultados indicaram nível médio de bem-estar no trabalho e diferenças entre as categorias profissionais e regime de contratação quanto à satisfação com salário e promoções, o que pode refletir na qualidade do atendimento prestado aos pacientes do hospital universitário.

Descritores: Enfermagem; Satisfação no Trabalho; Hospitais Universitários.

\section{Evaluación del bienestar en el trabajo entre los profesionales de enfermería de un hospital universitario}

\begin{abstract}
Bienestar en el trabajo se apoya en la Psicología Positiva, siendo definido como un estado psicológico compuesto por vínculos afectivos positivos con el trabajo y con la organización. Este estudio tuvo por objetivo conocer el nivel de bienestar en el trabajo de profesionales de enfermería que actúan en un hospital universitario e identificar diferencias entre categorías ocupacionales y tipos de contrato de trabajo. La muestra fue compuesta por 340 profesionales que contestaron escalas válidas de los constructos: Satisfacción en el Trabajo, Envolvimiento con el Trabajo y Comprometimiento Organizacional Afectivo. Para análisis de los datos se utilizó el programa SPSS, versión 12, para efectuar estadísticas descriptivas y testes de diferencia entre medias. Los resultados indicaron nivel medio de bienestar en el trabajo y diferencias entre las categorías profesionales y régimen de contratación en cuanto a la satisfacción con salario y promociones, lo que puede reflejar en la calidad del servicio prestado a los pacientes del hospital universitario.
\end{abstract}

Descriptores: Enfermería, Satisfacción en el Trabajo, Hospitales Universitarios.

\section{Introduction}

The hospital context has certain specific aspects within the world of work, and also brings together different professional staff, types of knowledge, technology and infrastructure ${ }^{(1)}$. Its technical and social configuration is unique, as also through the different models for action which are based on the competences, types of knowledge and multiple strategies of the professional $\operatorname{staff}^{(1)}$. It is in this context that the work of several different professional people in the health area is developed, including nursing.

The provision of assistance as an activity of the nursing team is different according to the functional category $^{(2)}$. Nurses are responsible for carrying out the management of care, which is the planning of nursing actions, the supply and arrangement of materials, and also care for the most seriously ill patients, who need specific care and decision making. The technician and the nursing assistant carry out medium-level tasks such as guidance and monitoring of the nursing work in an assistant role under supervision, and also assistential actions in the nursing area, except those which are exclusive responsibilities of the nurse.

Nursing assistance in state-run institutions deserves the attention of researchers and also of Government 
administrators, as it has been penalised with the lack of human and material resources, thereby breeding dissatisfaction among the professional themselves, who feel frustrated and impotent with this situation ${ }^{(3)}$, which interferes directly with the quality of the assistance provided to the population. In this context, well-being is an issue which has warranted growing attention from several researchers.

The concept of well-being appears in several different forms within the realm of Psychology, showing that the people who study the issue see it in different ways, either from a hedonistic standpoint (subjective well-being)(4), a view based on intrinsic potentialities (psychological well-being)(5), as a vision based on skills in relationships and social insertion (social well-being) (6) or seeing it as a set of positive associations with the work context (well-being at work) ${ }^{(7)}$. The proposal of the concept of well-being in the workplace opens a new possibility of investigation based on Positive Psychology and has the main focus on the positive aspects of individuals and also organisations, which is a position against the line which gives emphasis to illnesses and the mechanism of being taken ill(8).

The construct of well-being in the workplace, which is often known in specialised literature as BET, can be represented in three different dimensions ${ }^{(7)}$ : satisfaction in the workplace as "(...) a positive emotional state or a state of pleasure, resulting from work or from work experiences"(9); involvement with work, being defined as "(...) extent to which the performance of a person at his or her job affects self-esteem"(10); and affective organisational commitment, defined as "(...) a state in which the individual person identifies himself or herself with a particular institution and its objectives, seeking the maintenance of his or her ties to the institution considered, in a move to achieve such objectives"(11). Therefore, well-being in the workplace is a multidimensional psychological construct including positive affective ties with the workplace (satisfaction and involvement) and also with the organisation (affective commitment)(7).

It is also important to remember that well-being in the workplace brings consequences in areas such as performance, absenteeism and also staff turnover within the organisations ${ }^{(12)}$. This justifies the interest on the part of Brazilians to conduct research into wellbeing in the workplace, especially those dedicated to the issue of Organisational Behaviour. Even though there are already some studies about satisfaction within the nursing profession(13), few have sought to analyse the BET construct among these professionals. In specialised
Brazilian literature, we can mention one study by the Evandro Chagas Institute for Clinical Research (Instituto de Pesquisa Clínicas Evandro Chagas)(14), where the main factors that seemed to have contributed towards well-being in the workplace were the distinction of quality of service, the prestige of the institution, unwavering concern with the prevention of accidents in the workplace, a sufficient quantity of material to carry out the work, and also the affective ties with the clients, these factors being associated with staying in the profession and in the job.

Another study sought to assess well-being in the workplace through the job satisfaction among nurses in a private hospital and in a philanthropic hospital(15). The results of this study showed that the instrumental support received to carry out the activities and also the identification with the profession as important factors for promoting satisfaction among nurses. In addition, the satisfaction with the superiors was higher than satisfaction with colleagues, while factors related to promotion and salary were the ones that had the lowest average satisfaction ratings. Along the same lines, this study also seeks to investigate the level of well-being in the workplace (BET) of nursing professionals who work in a University hospital and also check for possible differences between the groups from different categories within the nursing profession and also different work regimes.

\section{Method}

The data was collected at a University hospital, in the region known as the Minas Gerais Triangle (Triângulo Mineiro), in the State of Minas Gerais, Brazil. This Hospital is a state-run institution, totally dedicated to patients from the Brazilian Government Single Health System (Sistema Único de Saúde - SUS). It is accredited as a high-complexity hospital, currently has 510 beds, and provides medical assistance in several different areas within the medical profession, being a reference and macrorregional hub for more than 30 municipalities.

The study has been publicised in all nursing management teams, seeking to obtain a diversified sample. Even though authorisation was granted by the management of the hospital and also the nursing management teams, only the workers who decided to participate in the study at their own free will would indeed participate in the work.

The participants are distributed in several sectors, under six management teams: Emergency Room, Child and Maternity Unit, Hospital Admittance, Special Units, 
Surgery Building and Outpatient Rooms. There is also a difference in the labour link with the institution, as workers could either be celetistas, meaning that they were hired through a selection process and are governed by the Brazilian Consolidated Labour Laws (Consolidação das Leis do Trabalho - CLT), or estatutários, who are those who entered via a Civil Service Entrance Exam (concurso público) and are governed by the Single Judicial Regime (Regime Jurídico Único - RJU).

The sample consists of 340 nursing professionals regularly employed at this hospital, out of a total of 1,248 (27.2\% of the workforce) who showed interest and time availability to collaborate during the data collection period, which covered 3 months. Due to this characteristic of free participation, the sample can be defined as non-probabilistic by convenience. Statistical strength is defined by three different factors: size of the effect, alpha and size of sample ${ }^{(16)}$. Based on the criteria as proposed by Cohen ${ }^{(17)}$, there was a post-hoc test after the study, using the GPower 3.1 programme, considering two independent samples (estatutários and celetistas) and three groups (nurses, nursing technicians and nursing assistants). The criterion used has been that of $\alpha=0.05$ and size effect $(d)=0.8$ (large), and there was the identification of $\mathrm{t}(338)=1.9670$ and strength $=0.999$ in the case of the independent samples. The statistical strength for the three groups $(\alpha=0.05$, size of effect $f=0.40$ - large) showed $F(2.337)=3.869$ and strength $=0.999$. Therefore, the total number of participants showed itself to be appropriate for the statistical analyses as carried out.

The instrument for collection of data was a selfapplicable questionnaire in four parts, three being scales for measurement of the study variables and also a questionnaire for personal and organisational data, as described below.

The Work Satisfaction Scale (Escala de Satisfação no Trabalho - EST)(18) is a multidimensional measurement, constructed and validated with the aim of assessing the degree of content of the worker when faced with different dimensions of his or her work. To answer the questions, the participant has a seven-point Likert scale, ranging from Totally Dissatisfied $(=1)$ to Totally Satisfied $(=7)$, with the average point being Indifferent $(=4)$. The reduced form of this scale consists of five factors with three items for each: Satisfaction with Colleagues $(\alpha=0.81)$, Satisfaction with Management ( $\alpha=0.84)$, Satisfaction with the Task $(\alpha=0.77)$, Satisfaction with Salaries $(\alpha=0.90)$ and Satisfaction with Promotions $(\alpha=0.81)$.
The Work Involvement Scale (Escala de Envolvimento com o Trabalho - EET) ${ }^{(18)}$ is a unifactorial measure comprising five items $(\alpha=0.78)$, with answers being given using a seven-point Likert scale ranging from Totally Disagree $(=1)$ to Totally Agree $(=7)$, and with a midpoint at "Neither Agree nor Disagree" $(=4)$. The involvement of an individual is defined as the extent to which the work carried out brings satisfaction to the person, absorbing him or her completely while the tasks are being carried out, and also being important for his or her life.

The Scale for Affective Organisational Commitment (Escala de Comprometimento Organizacional Afetivo - $E C O A)^{(18)}$, in its reduced form, contains five items assessing the types of affection that the worker has for his or her workplace, with a confidence coefficient of 0.95 . To reply, the subjects used a five-point Likert scale ranging from 1 (None) to 5 (Extremely), with a midpoint of 3 (More or less), to gauge the extent of their satisfaction with the organisation.

The last part of the questionnaire contained additional complementary data such as personal information (sex, age and marital status) and the professional information (work sector, shift, qualification time, time working in the institution, professional category and regime of hiring).

For the study to progress, there was a need for ethical procedures at a personal and institutional level, followed by collection, analysis and interpretation of data.

Thus, after due analysis and approval of the Project by the Research Ethics Committee of the institution, under protocol number 463/10, the procedure for data collection got under way. For this, it was necessary to get the approval of the University Hospital for the application of instruments on their premises, with their collaborators, outside their working hours. Next, prior contact was made with the people responsible for different segments when they were informed about the purpose of the survey, the format of the questionnaire, the duration of the application thereof, the acquiescence of the institution to allow the collection of data in the work environment, as also the care that involves scientific research. After this clarification with the parties responsible, agreement was reached about the best time to collect the data in each segment. Once again, at the time and venue as agreed, the researcher contacted each of the workers as present, who had been notified in advance about the conducting of the study in his or her segment. During this contact, information about the 
study was provided, stressing that participation was voluntary and that the anonymity of the participants would be respected, it also being stressed that there would be no kind of punishment or loss of any kind if the person decided not to participate. If the collaborator showed interest in participating but was not available at that moment, then a new visit would be arranged, to be held at his or her workplace.

Those who were available signed a Declaration of Free and Clarified Consent to grant authorisation, and then the data was collected on an individual basis.

Once the data had been collected, all answers were then transcribed onto a spreadsheet of the statistical computer programme, SPSS - Statistical Package for the Social Sciences (SPSS), release 12, for due analysis. The database included personal and professional variables, duly coded, and the answers given for each item on the three scales and subscales.

First, the data analysis was made with the aim of checking the precision of data entry, missed answers, extreme cases and also normality of variables. Next, descriptive statistics were produced for the participants' answers, and then performing difference tests between the means of groups regarding the different contract regimes (estatutário or celetista) and category (nurses, nursing technicians and nursing assistants).

\section{Results}

The analysis of the personal and professional data for the sample showed that most of the participants were female $(81.5 \%)$, married $(53.8 \%)$ and were distributed among the morning (31.1\%), afternoon (25.0\%) and night $(29.9 \%)$ shifts, with $14 \%$ of the sample working two shifts. In relation to the work segment, most of them were from the hospital admittance area (29.7\%), followed by the child and maternity area (24.4\%), outpatient rooms $(12.6 \%)$, special units department $(10.9 \%)$, emergency treatment department $(8.8 \%)$ and surgical block (5.9\%).

The average age was 38.61 years $(S D=9.62 \%)$, with the minimum age being 20 years and the maximum 59 years. Regarding the professional category, 109 (32.1\%) were nurses, 124 (36.5\%) nursing technicians and 107 (31.5\%) were nursing assistants; in relation to the employment regime, 228 (67.1\%) were estatutários and $112(32.9 \%)$ celetistas. The average time after graduation was 14.39 years $(S D=9.52)$ and the average time working at the institution was 11.8 years $(\mathrm{SD}=8.78)$.

Seeking to check the reliability of each instrument for the sample considered in this study, we calculated the Cronbach alpha coefficient, which showed results close to those of the original studies, and which showed a good internal consistency between the scales, with values ranging between 0.73 and 0.93 .

To assess the levels of well-being in the workplace for this sample, we have calculated the means and standard deviations on the scales (Table 1). The means thus obtained show that the satisfaction with colleagues (Mean=4.4, SD=1.0) and satisfaction with the task in the sample $(M=4.5, S D=1.1)$ were somewhere between "indifferent" and "satisfied". In relation to satisfaction with the bosses $(M=4.8, S D=1.2)$, the participants are, on average, almost satisfied. In relation to satisfaction with salaries, the sample is between "dissatisfied" and "indifferent" $(M=3.6 ; S D=1.6)$. Finally, regarding satisfaction with promotions $(M=3.0, S D=1.4)$, the collaborators tend to show dissatisfaction.

The degree of involvement with the job has been assessed with a mean of $4.0(S D=1.4)$, which corresponds to the option "neither agree nor disagree" on the reply scale, which shows a certain degree of indifference or suspicion of the participants, at that moment, about the ability of their current work to absorb them.

The analysis of affective organisational commitment has shown an average equal to $2.9(\mathrm{SD}=0.9)$, which could show weak affective commitment towards the organisation, as the feelings of pride, content, enthusiasm, interest and good spirits are "more or less" perceived in relation to the hospital where they work.

The standard deviations as obtained for each scale and subscale, close to 1 , show that there has been little variation in the answers in the sample considered. Greater variability was observed in the case of satisfaction with salaries and promotions, and also for the degree of involvement with the job.

Table 1 - Measurements of central tendency for participants, according to the variables of Well-Being in the Workplace $(\mathrm{N}=340)$

\begin{tabular}{|c|c|c|c|c|}
\hline Variables & M & DP & Midpoint & Reply Scale \\
\hline Satisfaction with colleagues & 4.44 & 1.03 & 4 & $1-7$ \\
\hline Satisfaction with salaries & 3.57 & 1.62 & 4 & $1-7$ \\
\hline Satisfaction with superiors & 4.79 & 1.21 & 4 & $\begin{array}{l}1-7 \\
\text { (continu }\end{array}$ \\
\hline
\end{tabular}


Table 1 - (continuation)

\begin{tabular}{lcccc}
\hline \multicolumn{1}{c}{ Variables } & M & DP & Midpoint & Reply Scale \\
\hline Satisfaction with tasks & 4.47 & 1.13 & 4 & $1-7$ \\
Satisfaction with promotions & 3.02 & 1.45 & 4 & $1-7$ \\
Involvement with the Job & 4.02 & 1.43 & 4 & $1-7$ \\
Affective Organisational Commitment & 2.94 & 0.96 & 3 & $1-5$ \\
\hline
\end{tabular}

To identify the differences between the groups with regard to the variables of this study, we have performed analyses of variance (ANOVA) and Student t-tests for independent samples. For these analyses, the groups were established based on the employment regime (celetistas and estatutários) and also the professional category (nurses, nursing technicians and nursing assistants).
The statistical analyses based on the t-test have shown a significant difference when it comes to satisfaction with salaries $(t=12.13 ; \mathrm{p}=0.001)$ and also regarding satisfaction with promotions $(t=4.85$; $\mathrm{p}=0.001$ ), with the estatutários showing greater satisfaction with salaries $(M=4.20)$ and also with promotions $(M=3.28)$ when compared with the group of celetistas (Table 2).

Table 2 - A comparison between means for the different variables of Well-Being in the Workplace, according to the employment regime of the participants $(N=340)$

\begin{tabular}{|c|c|c|c|c|c|c|}
\hline \multirow{2}{*}{ Variable } & \multicolumn{2}{|c|}{ Estatutários } & \multicolumn{2}{|c|}{ Celetistas } & \multirow{2}{*}{$\mathbf{t}$} & \multirow{2}{*}{ p } \\
\hline & M & SD & M & SD & & \\
\hline Satisfaction with colleagues & 4.48 & 1.03 & 4.37 & 1.03 & 0.91 & ns \\
\hline Satisfaction with salaries & 4.20 & 1.37 & 2.30 & 1.34 & 12.13 & 0.001 \\
\hline Satisfaction with superiors & 4.79 & 1.25 & 4.78 & 1.15 & 0.04 & Ns \\
\hline Satisfaction with tasks & 4.49 & 1.12 & 4.42 & 1.16 & 0.52 & Ns \\
\hline Satisfaction with promotions & 3.28 & 1.37 & 2.50 & 1.45 & 4.85 & 0.001 \\
\hline Involvement with the Job & 4.03 & 1.49 & 3.99 & 1.31 & 0.23 & Ns \\
\hline Affective Organisational Commitment & 2.93 & 0.96 & 2.96 & 0.97 & -0.23 & Ns \\
\hline
\end{tabular}

Student t-test; ns = not significant

To compare the responses of the groups divided by professional category, we have used ANOVA (analysis of variance using the Snedecor $F$ system), which showed few significant differences between nurses, technicians and nursing assistants (Table 3). A difference was observed in relation to satisfaction with salaries ( $F=11.75$ $(2,337) ; p=0.001)$ which, using the Tukey DHS test, was confirmed between the group of nursing technicians and nurses, and also between nursing technicians and nursing assistants, meaning that the nursing technicians were less satisfied with their salaries $(M=3.03)$ than the other two groups considered, which show no difference between them in relation to satisfaction with salaries.

Table 3 - A comparison between the means of the variables for Well-Being in the Workplace, considering the different professional categories $(\mathrm{N}=340)$

\begin{tabular}{|c|c|c|c|c|c|c|c|c|}
\hline \multirow{2}{*}{ Variable } & \multicolumn{2}{|c|}{ Nurses } & \multicolumn{2}{|c|}{ Nursing Technicians } & \multicolumn{2}{|c|}{ Nursing Assistants } & \multirow{2}{*}{$\mathbf{F}$} & \multirow{2}{*}{$\mathbf{p}$} \\
\hline & $\mathbf{M}$ & SD & $\mathbf{M}$ & SD & $\mathbf{M}$ & SD & & \\
\hline Satisfaction with colleagues & 4.41 & 1.08 & 4.48 & 1.03 & 4.41 & 0.99 & 0.18 & ns \\
\hline Satisfaction with salaries & 3.86 & 1.55 & 3.03 & 1.71 & 3.92 & 1.44 & 11.75 & 0.001 \\
\hline Satisfaction with superiors & 4.83 & 1.19 & 4.65 & 1.26 & 4.91 & 1.18 & 1.38 & ns \\
\hline Satisfaction with tasks & 4.61 & 1.09 & 4.41 & 1.17 & 4.40 & 1.13 & 1.17 & ns \\
\hline Satisfaction with promotions & 3.49 & 1.24 & 2.65 & 1.56 & 2.97 & 1.38 & 10.45 & 0.001 \\
\hline Involvement with the Job & 4.00 & 1.33 & 4.01 & 1.48 & 4.04 & 1.48 & 0.03 & ns \\
\hline Affective Organisational Commitment & 2.96 & 1.03 & 2.93 & 0.94 & 2.94 & 0.92 & 0.02 & ns \\
\hline
\end{tabular}

Snedecor $\mathrm{F}$ test; $\mathrm{ns}=$ not significant 
Also using ANOVA, significant differences were seen between the groups, for satisfaction with promotions ( $F=$ $10.45(2,337) ; p=0.001)$. The Tukey DHS test showed that the main significant difference is between nurses and nursing technicians and also between nurses and nursing assistants, with the nurses being significantly more satisfied with promotions in the workplace $(\mathrm{M}=$ 3.49) than the other two groups.

\section{Discussion}

The results for well-being in the workplace for the nursing professionals in a state-run hospital have shown a fragile affective commitment of these towards the organisation and also doubts concerning the degree of involvement in the work. Regarding satisfaction at work, the highest rating was that of satisfaction with superiors, when the sample showed itself to be almost satisfied. Regarding satisfaction with the task and with the colleagues, they are half satisfied and half indifferent. In terms of satisfaction with salaries, they were between dissatisfied and indifferent, and then finally, in relation to promotions, they were dissatisfied. Therefore, the participants in this study have shown an experience in the workplace that can be considered average.

In a study conducted with nursing professionals ${ }^{(19)}$ it was found that pleasure in working lies in completed tasks which, when you think of it, is the very maintenance of life. However, the fact is that the work is often carried out under inadequate conditions, with long working days, pressure from above, pressure from colleagues and even pressure from patients. Dissatisfaction is common, much more due to the non-acknowledgement of the effort that is made, and little value given, rather than through the precarious conditions to which they are subjected $^{(19)}$.

In general, studies on satisfaction with salaries among Brazilian workers have shown a trend towards high dissatisfaction(20). One conditioning factor that has caused the low pay and low value assigned to the nursing personnel is related to the very historical development of nursing work, related to the Christian values of charity and brotherhood, as a way of salvation of the soul(20). In spite of the growing professional development of nursing services, the image of this profession has remained associated with such values as kindness and humanism, slamming the brakes on the level of requests of the category.

It is also worth stressing that this hospital was going through a process of change and conflict at the moment of data collection, due to the additional pay for hospital standby hours being given only to the estatutários, possible layoffs among the celetistas and also outsourcing operations which occurred during this period.

This period of instability and layoffs during data collection could have had an influence on the results of this survey, as the reduction of the number of people working in a hospital could reduce the general levels of satisfaction and well-being at work ${ }^{(21)}$. Both the organisational reengineering as also the headcount reduction have a negative effect on the general wellbeing of the collaborators ${ }^{(22)}$.

When the answers from the estatutários and celetistas are compared, we see that the former group is more satisfied with salaries and promotions. One explanation for this fact could be the presence of a career plan only for this group.

Comparing the categories of nursing, we saw differences between the groups only in relation to satisfaction with salaries and promotions, with the nursing technicians showing less satisfaction with salaries when compared to the other groups, and with the nurses being more satisfied with promotions when compared with nursing technicians and nursing assistants. These differences seem to reflect differences between expected and actual income from different professional categories and hiring regimes.

A survey carried out by a team of researchers led by Linda Aiken, from the University of Pennsylvania, interviewed 43,329 nurses of 711 hospitals in five different countries (the United States, Canada, Germany, England and Scotland). In four of the five countries it was observed that $40 \%$ of the nurses said they were dissatisfied with their current work and the author suggested that this dissatisfaction in relation to their jobs could be responsible for the deterioration of the quality of nursing care ${ }^{(23)}$, as when people are more satisfied in their Jobs this has a daily reflection on benefits for better patient care(24).

In addition, the relationship between job satisfaction and health is already well known. People who are not satisfied at work tend to be taken ill(25), bringing, as a consequence, an increase in absenteeism, which is a worrying occurrence in the nursing profession because it causes disorganisation and hence reduces the quality of assistance provided to the patients ${ }^{(26)}$.

\section{Conclusions}

The results of the study have shown that, on average, the levels of satisfaction with the aspects 
as assessed are between "dissatisfied" and "almost satisfied", and that the level of involvement with the job and also of affective organisational commitment towards the hospital where they work is intermediate. This result is a cause for concern, as medium levels of well-being in the workplace (BET) may, as already discussed, interfere directly with the quality of the assistance provided to the needy population and also affect the general health of these professional people.

The differences observed between the three professional categories and the two hiring regimes were similar, in relation to satisfaction with salaries and promotions. One possible explanation for this result is the career plan which is available only to the estatutários. These differences also seem to reflect discrepancies between expected and actual income of the different professional categories. To confirm these results, it shall be necessary to conduct a deeper investigation, and this could also clarify if the process of change and conflict as present at the moment of data collection could have affected the results as obtained.

One of the limitations of this study was the fact that it was carried out in only one University Hospital in the interior of the State of Minas Gerais, meaning that the generalisation of the results is limited. Later studies, at this same hospital, could show if, after stabilisation, the level of well-being in the workplace would be altered or not. However, the results of this study have made a contribution to existing literature, as Brazilian academic works focusing on this specific population or workers in the health sector are extremely rare. The average level of well-being in the workplace as identified in this study suggests the need for a greater awareness of its causes, which shall allow the development of a proposal for change seeking to improve this level, also considering that the quality of service provided to the general population may be affected by the well-being of the workers, as also the very health of the nursing professionals.

\section{Referências}

1. Pinho DLM, Abrahão JI, Ferreira MC. As estratégias operatórias e a gestão da informação no trabalho de enfermagem, no contexto hospitalar. Rev. Latino-Am. Enfermagem. 2003;11(2):168-76.

2. Lei n. 7498 de 25 de junho de 1986 (BR). Dispõe sobre a regulamentação do exercício da Enfermagem e dá outras providências. Legislação e Normas do CORENMG. Belo Horizonte; ago 2005.
3. Spindola T, Martins ERC, Lopes GT. A prática de enfermagem nos hospitais universitários - percepção dos enfermeiros. Esc Anna Nery. 2001;5(2):181-90.

4. Diener E, Suh E, Oishi S. Recent findings on subjective well-being. Indian J Clin Psychol. 1997;24(1):25-41.

5. Ryan RM, Deci EL. On happiness and human potentials: A review of research on hedonic and eudaimonic wellbeing. Annual Rev Psychol. 2001;52:141-66.

6. Keys CL. Social Well-Being. Soc Psychol Q. 1998;61(2):121-40.

7. Siqueira MMM, Padovam VAR. Bases teóricas de bemestar subjetivo, bem-estar psicológico e bem-estar no trabalho. Psicol Teoria e Pesqui. 2008;24(2):201-9.

8. Araújo PM, Oliveira AF. Bem-estar no trabalho: impacto das percepções dos valores organizacionais e da confiança do empregado na organização. Rev Horizonte Científico. 2006;2(1):1-26.

9. Locke EA. The nature and causes of job satisfaction. In Dunnette MP, organizador. Handbook of Industrial and Organizational Psychology. Chicago: Rand-McNally; 1976. $1500 \mathrm{p}$.

10. LodahI TM, Kejner M. The definition and measurement of job involvement. J Appl Psychol. 1965;49(1):24-33.

11. Mowday RT, Steers RM, Porter LW. The measurement of organizational commitment. J Vocational Beh.1979;14:224-47.

12. Siqueira MMM, Barbosa T, Ferraz C. Análise de estudos brasileiros sobre o bem-estar no trabalho. $\mathrm{V}$ Seminário de Pesquisa GIBEST: grupo interinstitucional de pesquisa de bem-estar, suporte social e trabalho. São Bernardo do Campo; 2008.

13. Cura MLAD, Rodrigues ARF. Satisfação profissional do enfermeiro. Rev. Latino-Am. Enfermagem. 1999;7(4):21-8.

14. Silveira GRM. Trabalho e saúde no hospital: O caso das trabalhadoras de Enfermagem do Instituto de Pesquisa Clínica Evandro Chagas [dissertação de mestrado]. Rio de Janeiro (RJ): Escola Nacional de Saúde Pública Sérgio Arouca da Fundação Oswaldo Cruz; 2003.

15. Simoni EM. A organização hospitalar: um estudo sobre os fatores que influenciam na satisfação das enfermeiras [dissertação de mestrado]. Salvador (BA): Faculdade de Administração, Universidade de Salvador; 2007.

16. Hair JF, Anderson RE, Tatham RL, Black WC. Análise multivariada de dados. $5^{a}$ ed. Porto Alegre: Bookman; 2005. 600p.

17. Cohen J. Statistical power analysis for the behavioral sciences. New York: Academic Press; 1977. 474 p. 
18. Siqueira MMM, organizador. Medidas do comportamento organizacional: ferramentas de diagnóstico e de gestão. Porto Alegre: Artmed; 2008. $344 \mathrm{p}$.

19. Elias MA, Navarro VL. A relação entre o trabalho, a saúde e as condições de vida: negatividade e positividade no trabalho das profissionais de enfermagem de um hospital escola. Rev. Latino-Am. Enfermagem. 2006;14(4):517-25.

20. Siqueira MM, Watanabe FS, Ventola A. Desgaste físico e mental de auxiliares de enfermagem: uma análise sob enfoque gerencial. Rev. Latino-Am. Enfermagem. 1995;3(1):45-57.

21. Helogren J, Sverke M. Unionized employees perceptions of role stress and fairness during organizational downsizing: consequences for job satisfaction, union satisfaction and well-being. Econom Ind Democr. 2001;22(4):543-67.

22. Østhus S. For better or worse? Workplace changes and the health and well-being of norwegian workers. Work, Employment Soc. 2007;21(4):731-50.

23. Marziale MHP. Enfermeiros apontam as inadequadas condições de trabalho como responsáveis pela deterioração da qualidade da assistência de enfermagem. . Rev. Latino-Am. Enfermagem. 2001;9(3):1.

24. Martins JT, Robazzi MLCC, Plath GA. Satisfação e insatisfação entre auxiliares e técnicos de enfermagem de uma unidade de internação feminina de um hospital escola. Ciênc Enferm. 2007;13(1):25-33.

25. Paravic T. Satisfação no trabalho de mulheres acadêmicas da Universidade de Concepción, Chile [tese de doutorado]. São Paulo (SP): Escola de Enfermagem de Ribeirão Preto da Universidade de São Paulo; 1998. $271 \mathrm{p}$.

26. Silva DMPP, Marziale MHP. Absenteísmo de trabalhadores de enfermagem em um hospital universitário. Rev. Latino-Am. Enfermagem. 2000;8(5):44-51. 